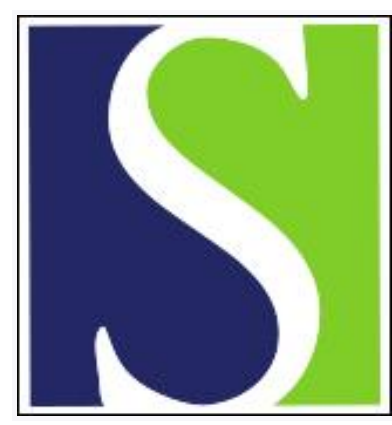

Scand J Work Environ Health 2004;30(6):425-437

https://doi.org/10.5271/sjweh.831

Issue date: Dec 2004

\title{
Cancer among meat industry workers
}

by McLean D, Pearce $\mathrm{N}$

Affiliation: Centre for Public Health Research, Massey University Wellington Campus, Private Box 756, Wellington, New Zealand. n.e.pearce@massey.ac.nz

Refers to the following text of the Journal: 2002;28 suppl 1:1-88

Key terms: abattoir; cancer; hematologic neoplasm; leukemia; lung cancer; lymphoma; meat industry worker; meat product; occupational disease; occupational exposure; review; slaughterhouse

This article in PubMed: www.ncbi.nlm.nih.gov/pubmed/15633593 


\title{
Cancer among meat industry workers
}

\author{
by Dave McLean, PhD, ${ }^{1,2}$ Neil Pearce, $P h D^{1}$
}

\begin{abstract}
McLean D, Pearce N. Cancer among meat industry workers. Scand J Work Environ Health 2004;30(6):425-437.
Several studies have found increased risks of cancer among workers in the meat industry, particularly lung and hematologic cancers. Relevant publications were obtained through a computerized literature search with the key words "cancer", "lung cancer", "hematologic neoplasms", "meat products", "abattoirs", and "slaughterhouses", and the evidence available from analyses of routine data, proportionate mortality and incidence studies, and cohort and case-control studies was reviewed. These analyses suggest a significant excess lung cancer risk among meat workers. This risk was associated the most strongly with exposure to animal slaughtering or freshly slaughtered meat or to biological material contained in blood and animal fecal matter, and it was greater than could be attributed to smoking. This finding suggests an etiologic role for biological exposure; however, the specific exposure(s) responsible are unknown, and further research is clearly required. The results of studies of hematologic cancers have been less consistent, but they suggest a small excess risk for leukemia in association with similar exposures.
\end{abstract}

Key terms abattoir; neoplasm, hematologic; leukemia; cancer, lung; lymphoma; product, meat; disease, occupational; exposure, occupational; review; slaughterhouse.

Several studies have found increased risks of cancer among workers exposed to meat and meat products, particularly lung cancer and hematologic cancers. In this paper the evidence available from published studies on cancer among workers in the meat industry, analyses of routinely collected mortality and incidence data, proportionate mortality and incidence studies, cohort studies, and case-control studies was reviewed. Finally, we have summarized the evidence for a causal association between work in the meat industry and increased risks for each cancer type and discussed potential exposures in the industry.

\section{Studies of cancer among workers in the meat industry}

We reviewed publications obtained through searching computerized databases of the medical literature, and in particular Medline, since 1966. Variations on the key words "cancer", "lung cancer", "hematologic neoplasms", "meat products", "abattoirs", and "slaughterhouses" were used, and relevant articles cited in those identified through this search were also obtained. Where 95\% confidence intervals were not reported, they were calculated using Rothman's formula for standardized mortality ratios (SMR) (1) and Cornfield confidence intervals for odds ratios (OR) (2).

\section{Analyses of routine mortality and incidence records}

The observation of an excess risk of lung cancer among butchers was first reported at a symposium in Finland in 1981 (3). Subsequently several short reports, based on analyses of routinely collected data on mortality and cancer incidence that compared occupational categories, appeared in the literature (4-6) (table 1). The first such report was a review of Danish occupational mortality data for the period 1970-1975 (4). In the same year analyses of routine data from England and Wales, Denmark, and Sweden showing similar risk were reported (5), and it was subsequently noted that similar excesses had previously been reported in the occupational mortality reports of both the 1951 and 1961 censuses in England and Wales (6).

The most striking feature of these reports was the consistency of the findings over a 30-year period in five countries, and an early review concluded that the excess was real and unlikely to be attributable to smoking (7). It was also apparent that the risk was higher for "butchers in slaughterhouses" than for those categorized

1 Centre for Public Health Research, Massey University Wellington Campus, Wellington, New Zealand.

2 International Agency for Research on Cancer, Lyon, France.

Reprint requests to: Professor Neil Pearce, Centre for Public Health Research, Massey University Wellington Campus, Private Box 756, Wellington, New Zealand. [E-mail: n.e.pearce@massey.ac.nz] 
Table 1. Analyses of routinely collected data on lung cancer in meat workers. (MOR = mortality odds ratio, PIR = proportionate incidence ratio, $\mathrm{RR}=$ relative risk, $\mathrm{SIR}=$ standardized incidence ratio, $\mathrm{SMR}=$ standardized mortality ratio, $95 \% \mathrm{Cl}=95 \%$ confidence interval)

\begin{tabular}{|c|c|c|c|c|c|c|c|}
\hline Reference & Country & Study period & Study type and population & $\begin{array}{c}\text { Risk } \\
\text { measure }\end{array}$ & $\begin{array}{l}\text { Observed } \\
\text { (N) }\end{array}$ & $\mathrm{RR}$ & $95 \% \mathrm{Cl}$ \\
\hline \multirow{11}{*}{$\begin{array}{l}\text { Lynge et al, } \\
1982 \text { (4) }\end{array}$} & Denmark & $1970-1975$ & Mortality among self-employed butchers & SMR & 17 & 1.6 & $1.0-2.5$ \\
\hline & Denmark & $1970-1975$ & Mortality among skilled butchers in butcher shops & SMR & 9 & 2.5 & $1.3-4.6$ \\
\hline & Denmark & $1970-1975$ & Mortality among skilled butchers in slaughterhouses & SMR & 15 & 1.7 & $1.0-2.8$ \\
\hline & Denmark & $1975-1980$ & Mortality among self employed butchers & SMR & 30 & 1.8 & $1.2-2.5$ \\
\hline & Denmark & $1975-1980$ & Mortality among skilled butchers in butcher shops & SMR & 5 & 0.9 & $0.3-1.9$ \\
\hline & Denmark & $1975-1980$ & Mortality among skilled butchers in slaughterhouses & SMR & 21 & 1.5 & $2.0-2.3$ \\
\hline & Denmark & $1975-1980$ & Mortality among unskilled workers in slaughterhouses & SMR & 35 & 1.1 & $0.8-1.5$ \\
\hline & Denmark & $1970-1980$ & Mortality among self employed butchers & SMR & 47 & 1.7 & $1.3-2.2$ \\
\hline & Denmark & $1970-1980$ & Mortality among skilled butchers in butcher shops & SMR & 14 & 1.5 & $0.9-2.4$ \\
\hline & Denmark & $1970-1980$ & Mortality among skilled butchers in slaughterhouses & SMR & 36 & 1.6 & $1.1-2.2$ \\
\hline & Denmark & $1970-1980$ & Mortality among unskilled workers in slaughterhouses & SMR & 51 & 1.0 & $0.8-1.3$ \\
\hline \multirow{9}{*}{$\begin{array}{l}\text { Fox et al, } \\
1982(5)\end{array}$} & England \& Wales & $1966-1967$ & Incidence among all male butchers & $\mathrm{PIR}$ & 286 & 1.3 & $1.1-1.4$ \\
\hline & England \& Wales & 1968-1970 & Incidence among all male butchers & PIR & 253 & 1.2 & $1.1-1.4$ \\
\hline & England \& Wales & 1970-1972 & Mortality among all male butchers & SMR & 260 & 1.2 & $1.0-1.3$ \\
\hline & Denmark & 1970-1975 & Mortality among butchers in slaughterhouses & SMR & 9 & 2.5 & $1.2-4.8$ \\
\hline & Denmark & $1970-1975$ & Mortality among butchers employed elsewhere & SMR & 32 & 1.7 & $1.2-2.3$ \\
\hline & Denmark & $1970-1975$ & Mortality among unskilled workers in slaughterhouses & SMR & 16 & 0.9 & $0.5-1.4$ \\
\hline & Sweden & $1961-1973$ & Incidence among butchers in slaughterhouses & SIR & 65 & 1.8 & $1.4-2.3$ \\
\hline & Sweden & $1961-1973$ & Incidence among butchers employed elsewhere & SIR & 12 & 1.3 & $0.7-2.2$ \\
\hline & Sweden & $1961-1973$ & Incidence among other staff in slaughterhouses & SIR & 52 & 1.5 & $1.1-1.9$ \\
\hline \multirow{3}{*}{$\begin{array}{l}\text { Griffith, } \\
1982 \text { (6) }\end{array}$} & England \& Wales & 1951 & Mortality among meat and fish curers and smokers & SMR & 10 & 2.0 & $1.0-3.6$ \\
\hline & England \& Wales & 1951 & Mortality among slaughterhouse workers & SMR & 17 & 1.3 & $0.8-2.0$ \\
\hline & England \& Wales & 1959-1963 & Mortality among butchers and meat cutters & SMR & 436 & 1.3 & $1.2-1.4$ \\
\hline \multirow{2}{*}{$\begin{array}{l}\text { Lagorio et al, } \\
1995 \text { (8) }\end{array}$} & Italy & 1981-1982 & Mortality among animal slaughterers in the food & MOR & 6 & 2.8 & $P<0.1$ \\
\hline & Italy & $1981-1982$ & $\begin{array}{l}\text { processing sector } \\
\text { Mortality among animal slaughterers in any economic sector }\end{array}$ & MOR & 7 & 2.5 & $P<0.1$ \\
\hline
\end{tabular}

as "butchers employed elsewhere" or "unskilled workers in slaughterhouses". Aggregating the data from these early analyses according to these exposure categories gave pooled estimates that reflected this distinction between slaughtering and simple contact with meat. The pooled estimate for "butchers in slaughterhouses" [SMR $1.71,95 \%$ confidence interval (95\%CI) 1.45-2.01] exceeded that for "butchers employed elsewhere" (SMR $1.29,95 \%$ CI 1.21-1.38) and for "unskilled workers in slaughterhouses" (SMR 1.14, 95\% CI 0.98-1.32). A similar excess among persons with an occupation recorded as animal slaughterer has also been observed in a recent Italian study of lung cancer mortality by industry and occupation on the basis of record-linkage between census records and death certificates (8).

A significant excess risk of leukemia was also observed for men whose occupation was recorded as "Food, meat processors", with the strongest association with the work category of "meat cutters and wrappers" [standardized incidence ratio (SIR) 2.25, 95\% CI 0.73-5.25, 5 cases], in a study using routine data that investigated leukemia incidence by occupation over the period 1963-1977 in the Portland-Vancouver area (9) in the United States.

\section{Proportionate mortality and cancer incidence studies}

In some of the investigations of meat industry workers proportional measures of mortality or incidence for a range of cancer types have also been calculated $(5,10-$ 14), and similar excesses have been observed (table 2). Excess proportionate incidence ratios (PIR) for lung cancer among male butchers in England and Wales were reported for two of the periods examined in the 1960s (5), although no elevation was observed for butchers and meat cutters working either within or outside of slaughterhouses during the period 1950-1979 in the state of Washington (10). In another study of 233 deaths occurring between 1965 and 1980 in male members of the meat cutters' union in Baltimore, Johnson \& Fischman reported excess mortality from all cancers and both lung and bladder cancer (11). Although the numbers were small, this investigation also suggested an association with lymphatic and hematopoietic cancer.

Johnson later reported a PMR analysis on a cohort of 28901 members of the Baltimore union employed between 1949 and 1979, investigated as separate subcohorts on the basis on ethnicity and gender (12-14). Within each subcohort, internal comparisons were possible through separate analyses carried out for subgroups defined according to lifetime work in slaughterhouses, meat-packing plants in which no slaughtering was done, meat and delicatessen departments of grocery stores and supermarkets, chicken slaughtering plants, and companies outside the meat industry. All cancers and lung cancer were consistently elevated in the subcohorts. 
Table 2. Proportionate mortality and proportionate incidence studies of cancer in meat workers. (PIR = proportionate incidence ratio, $\mathrm{PMR}=$ proportionate mortality ratio, $\mathrm{RR}=$ relative risk, US = United States)

\begin{tabular}{|c|c|c|c|c|c|c|}
\hline Cancer site ${ }^{a}$ & Country & Study period & Population studied & $\begin{array}{l}\text { Risk } \\
\text { measure }\end{array}$ & $\begin{array}{l}\text { Observed } \\
\text { (N) }\end{array}$ & $\mathrm{RR}$ \\
\hline \multicolumn{7}{|l|}{ All cancers (140-209) } \\
\hline $\begin{array}{l}\text { Johnson \& Fischman, } \\
1982 \text { (11) }\end{array}$ & US (Baltimore, MD) & $1965-1980$ & Meat-cutter union members & PMR & 56 & 1.16 \\
\hline \multirow{5}{*}{$\begin{array}{l}\text { Johnson et al, } \\
1986(12)\end{array}$} & \multirow[t]{5}{*}{ US (Baltimore, MD) } & \multirow[t]{5}{*}{$1949-1980$} & White male union members & PMR & 401 & 1.15 \\
\hline & & & White male union members in slaughterhouses & PMR & 125 & 1.21 \\
\hline & & & White male union members in meat packing plants & PMR & 76 & 1.25 \\
\hline & & & White male union members in supermarkets & PMR & 126 & 1.12 \\
\hline & & & White male union members in nonmeat plants & PMR & 43 & 1.07 \\
\hline \multirow{5}{*}{$\begin{array}{l}\text { Johnson et al, } \\
1986 \text { (13) }\end{array}$} & \multirow[t]{5}{*}{ US (Baltimore, MD) } & \multirow[t]{5}{*}{$1949-1980$} & White female union members & PMR & 178 & 1.09 \\
\hline & & & White female union members in slaughterhouses & PMR & 29 & 1.05 \\
\hline & & & White female union members in meat packing plants & PMR & 36 & 1.14 \\
\hline & & & White female union members in supermarkets & PMR & 67 & 1.22 \\
\hline & & & White female union members in nonmeat plants & PMR & 29 & 0.83 \\
\hline \multicolumn{7}{|l|}{ Lung cancer (162) } \\
\hline \multirow[t]{2}{*}{ Fox et al, $1982(5)$} & \multirow[t]{2}{*}{ England \& Wales } & $1966-1967$ & Among all male butchers & PIR & 286 & 1.27 \\
\hline & & $1968-1970$ & Among all male butchers & PIR & 253 & 1.20 \\
\hline \multirow[t]{2}{*}{ Milham, 1982 (10) } & \multirow[t]{2}{*}{ US (Washington, DC) } & \multirow[t]{2}{*}{$1950-1979$} & Butchers and meat cutters working in slaughterhouses & PMR & 28 & 1.07 \\
\hline & & & Butchers and meat cutters not in slaughterhouses & PMR & 89 & 0.97 \\
\hline $\begin{array}{l}\text { Johnson \& Fischman, } \\
1982 \text { (11) }\end{array}$ & US (Baltimore, MD) & $1965-1980$ & Meat cutters union members & PMR & 27 & 1.54 \\
\hline \multirow{4}{*}{$\begin{array}{l}\text { Johnson et al, } \\
1986(12)\end{array}$} & & \multirow[t]{4}{*}{$1949-1980$} & White male meat cutters' union members & PMR & 151 & 1.32 \\
\hline & & & White male members working in meatpacking plants & PMR & 31 & 1.57 \\
\hline & & & White male union members in supermarkets & PMR & 46 & 1.27 \\
\hline & & & White male union members in the nonmeat industry & PMR & 23 & 1.78 \\
\hline \multirow{3}{*}{$\begin{array}{l}\text { Johnson et al, } \\
1986(13)\end{array}$} & \multirow[t]{3}{*}{ US (Baltimore, MD) } & \multirow[t]{3}{*}{$1949-1980$} & White female union members & PMR & 38 & 2.10 \\
\hline & & & White female union members in meatpacking plants & PMR & 12 & 3.30 \\
\hline & & & White male union members in supermarkets & PMR & 14 & 2.18 \\
\hline \multicolumn{7}{|c|}{ Buccal cavity \& pharynx (140-149) } \\
\hline \multirow{3}{*}{$\begin{array}{l}\text { Johnson et al, } \\
1986 \text { (12) }\end{array}$} & \multirow[t]{3}{*}{ US (Baltimore, MD) } & $1949-1980$ & White male union members & PMR & 23 & 2.00 \\
\hline & & & White male union members in meatpacking plants & PMR & 6 & 2.93 \\
\hline & & & White female union members in meatpacking plants & PMR & 8 & 0.56 \\
\hline All lymphatic \& hematopc & ietic cancers $(200-208$ & & & & & \\
\hline Johnson et al, & US (Baltimore, MD) & $1949-1980$ & White male meat cutters' union members & PMR & 34 & 0.92 \\
\hline $1986(12)$ & & & White male union members working in slaughterhouses & PMR & 13 & 1.24 \\
\hline & & & White male union members in meat-packing plants & PMR & 4 & 0.62 \\
\hline & & & White male union members in supermarkets & PMR & 12 & 0.66 \\
\hline & & & White male union members in the nonmeat industry & PMR & 3 & 0.66 \\
\hline Johnson et al, & US (Baltimore, MD) & $1949-1980$ & White female union members & PMR & 10 & 2.17 \\
\hline $1986(13)$ & & & White female union members in slaughterhouses & PMR & 2 & 0.89 \\
\hline & & & White female union members in supermarkets & PMR & 10 & 2.17 \\
\hline Lymphosarcoma \& reticu & losarcoma (200) & & & & & \\
\hline $\begin{array}{l}\text { Johnson \& Fischman, } \\
1982 \text { (11) }\end{array}$ & US (Baltimore, MD) & $1965-1980$ & Meat-cutter union members & PMR & 2 & 2.67 \\
\hline Hodgkin's disease (201) & & & & & & \\
\hline Johnson et al, & US (Baltimore, MD) & $1949-1980$ & White male union members & PMR & 9 & 1.70 \\
\hline $1986(12)$ & & & White male union members in slauthterhouses & PMR & 4 & 2.92 \\
\hline & & & White male union members in supermarkets & PMR & 2 & 1.09 \\
\hline Myeloid leukemia (205) & & & & & & \\
\hline $\begin{array}{l}\text { Johnson \& Fischman, } \\
1982 \text { (11) }\end{array}$ & US (Baltimore, MD) & $1965-1980$ & White male union members & PMR & 3 & 3.75 \\
\hline Multiple myeloma (203) & & & & & & \\
\hline $\begin{array}{l}\text { Johnson \& Fischman, } \\
1982 \text { (11) }\end{array}$ & US (Baltimore, MD) & $1965-1980$ & White male union members & PMR & 2 & 2.74 \\
\hline
\end{tabular}

a Code of the ninth revision of the International Classification of Diseases in parentheses after the class of cancer.

\section{Cohort studies}

Several cohort studies of butchers and meat workers have subsequently been reported, including studies in Germany (15), the United States (based on the same
Baltimore union cohort) $(12-14,16,17)$, England and Wales $(18,19)$, Switzerland (20), Sweden (21), Australia (22), and New Zealand (23). These studies have allowed risks for all types of cancer to be evaluated, and, 
within the limitations of cohort size and the validity of the exposure categories used, they have allowed potential risk factors to be investigated. These studies are reviewed in this paper, with risk estimates as reported in the original articles (with calculated confidence intervals included where these were not reported) presented in table 3 . It should be noted that not all the entries in this table represent independent observations, as the studies in the United States and Sweden in particular represent repeated studies in the same, or overlapping, populations.

A more than twofold excess risk of lung cancer (ie, 36 cases among butchers but only 15 among bakers, $\mathrm{P}<0.01$ ) was reported as a chance (and previously unreported) finding in a German study that compared the mortality experience of 398 butchers with that of 399 bakers in Hamburg for the period 1954-1966 (15). Johnson also reported standardized mortality ratios for the
Baltimore union cohorts $(12-14,16,17)$, with an elevation in risk observed for all cancers among all but workers in the meat departments of supermarkets. Lung cancer risk was significantly elevated for both white male and female union members and for both men and women with lifetime employment in meatpacking plants and women with lifetime employment in the meat departments of grocery stores or supermarkets. The highest lung cancer rate observed was for nonwhite male slaughterhouse workers (SMR 2.1, P<0.005, 43 observed), although, among white males, the highest rate was found for the comparison group employed in the nonmeat companies. Additional follow-up of the workers in slaughterhouses and meatpacking plants showed a statistically significant elevation of lung cancer risk among the men and women and both ethnic groups studied, although lung cancer risk was virtually identical in

Table 3. Cohort studies of cancer in meat workers. (SMR = standardized mortality ratio, UK = United Kindom, US = United States, 95\% $\mathrm{Cl}=95 \%$ confidence interval)

\begin{tabular}{|c|c|c|c|c|c|}
\hline Cancer ${ }^{a}$ & Country & Exposure & $\begin{array}{l}\text { Observed } \\
\text { category }\end{array}$ & $\begin{array}{l}\text { SMR } \\
(N)\end{array}$ & $95 \% \mathrm{Cl}$ \\
\hline \multicolumn{6}{|l|}{ All cancers (140-208) } \\
\hline Johnson et al, 1986 (12) & US & All white males in union & 401 & 1.3 & $1.2-1.4$ \\
\hline Johnson et al, 1986 (13) & US & Women in union & 178 & 1.1 & $1.0-1.3$ \\
\hline Johnson et al, 1986 (12) & $\begin{array}{l}\text { US } \\
\text { US } \\
\text { US }\end{array}$ & $\begin{array}{l}\text { White males in slaughterhouses } \\
\text { White males in meatpacking plant } \\
\text { White males in supermarket }\end{array}$ & $\begin{array}{r}125 \\
76 \\
126\end{array}$ & $\begin{array}{l}1.3 \\
1.6 \\
1.2\end{array}$ & $\begin{array}{l}1.1-1.5 \\
1.3-2.0 \\
1.0-1.4\end{array}$ \\
\hline Johnson, 1989 (14) & $\begin{array}{l}\text { US } \\
\text { US }\end{array}$ & $\begin{array}{l}\text { Nonwhite males in slaughterhouses } \\
\text { Nonwhite male meat packers }\end{array}$ & $\begin{array}{l}43 \\
32\end{array}$ & $\begin{array}{l}1.2 \\
1.2\end{array}$ & $\begin{array}{l}0.9-1.6 \\
0.8-1.7\end{array}$ \\
\hline Coggon et al, 1989 (18) & UK & Meat industry & 87 & 1.1 & $0.9-1.3$ \\
\hline Guberan et al, 1993 (20) & Switzerland & Self-employed butchers & 157 & 1.3 & $1.1-1.4$ \\
\hline Johnson, 1994 (16) & $\begin{array}{l}\text { US } \\
\text { US }\end{array}$ & $\begin{array}{l}\text { Women in supermarket } \\
\text { Men in supermarket }\end{array}$ & $\begin{array}{l}153 \\
290\end{array}$ & $\begin{array}{l}1.0 \\
1.0\end{array}$ & $\begin{array}{l}0.9-1.2 \\
0.9-1.2\end{array}$ \\
\hline Johnson et al, 1995 (17) & $\begin{array}{l}\text { US } \\
\text { US }\end{array}$ & $\begin{array}{l}\text { Slaughterhouse } \\
\text { Meat packing plant }\end{array}$ & $\begin{array}{l}455 \\
343\end{array}$ & $\begin{array}{l}1.1 \\
1.2\end{array}$ & $\begin{array}{l}1.0-1.3 \\
1.1-1.3\end{array}$ \\
\hline Coggon \& Wield, 1995 (19) & UK & Butchers & 691 & 1.0 & $0.9-1.0$ \\
\hline Boffetta et al, 2000 (21) & Sweden & Butchers or meatpackers & 2417 & 1.1 & $1.0-1.1$ \\
\hline \multirow[t]{2}{*}{ Fritschi et al, 2003 (22) } & Australia & Male union members & 176 & 0.9 & $0.8-1.1$ \\
\hline & Australia & Female union members & 40 & 0.6 & $0.4-0.8$ \\
\hline McLean et al, 2004 (23) & New Zealand & Slaughterhouse workers & 227 & 1.1 & $1.0-1.3$ \\
\hline \multicolumn{6}{|c|}{ Buccal cavity and pharynx (140-149) } \\
\hline Johnson et al, 1986 (12) & US & White males in union & 23 & 2.3 & $1.5-3.3$ \\
\hline Guberan et al, 1993 (20) & Switzerland & Self-employed butchers & 6 & 1.0 & $0.4-2.0$ \\
\hline Johnson, 1994 (16) & $\begin{array}{l}\text { US } \\
\text { US }\end{array}$ & $\begin{array}{l}\text { Women in supermarket } \\
\text { Men in supermarket }\end{array}$ & $\begin{array}{r}3 \\
15\end{array}$ & $\begin{array}{l}1.5 \\
1.8\end{array}$ & $\begin{array}{l}0.3-4.4 \\
1.0-3.0\end{array}$ \\
\hline Johnson et al, 1995 (17) & $\begin{array}{l}\text { US } \\
\text { US }\end{array}$ & $\begin{array}{l}\text { Slaughterhouse workers } \\
\text { Meatpacking plant workers }\end{array}$ & $\begin{array}{l}12 \\
17\end{array}$ & $\begin{array}{l}1.1 \\
2.0\end{array}$ & $\begin{array}{l}0.6-1.9 \\
1.2-3.2\end{array}$ \\
\hline Boffetta et al, 2000 (21) & Sweden & Butchers or meatpackers & 73 & 1.1 & $0.8-1.3$ \\
\hline McLean et al, 2004 (23) & New Zealand & Slaughterhouse workers & 2 & 1.5 & $0.2-5.3$ \\
\hline \multicolumn{6}{|l|}{ Esophagus (150) } \\
\hline Johnson, 1989 (14) & $\begin{array}{l}\text { US } \\
\text { US }\end{array}$ & $\begin{array}{l}\text { Nonwhite males in slaughterhouses } \\
\text { Nonwhite male meat packers }\end{array}$ & $\begin{array}{l}2 \\
6\end{array}$ & $\begin{array}{l}0.8 \\
3.1\end{array}$ & $\begin{array}{l}0.2-2.6 \\
1.3-6.4\end{array}$ \\
\hline Guberan et al, 1993 (20) & Switzerland & Self-employed butchers & 9 & 1.4 & $0.7-2.5$ \\
\hline Johnson et al, 1995 (17) & $\begin{array}{l}\text { US } \\
\text { US }\end{array}$ & $\begin{array}{l}\text { Slaughterhouse workers } \\
\text { Meatpacking plant }\end{array}$ & $\begin{array}{l}19 \\
16\end{array}$ & $\begin{array}{l}1.7 \\
1.7\end{array}$ & $\begin{array}{l}1.0-2.6 \\
1.0-2.8\end{array}$ \\
\hline Coggon \& Wield, 1995 (19) & UK & Butchers & 15 & 0.7 & $0.4-1.2$ \\
\hline Boffetta et al, 2000 (21) & Sweden & Butchers or meatpackers & 38 & 1.3 & $0.9-1.8$ \\
\hline McLean et al, 2004 (23) & New Zealand & Slaughterhouse workers & 3 & 1.7 & $0.4-5.0$ \\
\hline
\end{tabular}


Table 3. Continued.

\begin{tabular}{|c|c|c|c|c|c|}
\hline Cancer $^{\mathrm{a}}$ & Country & Exposure & $\begin{array}{l}\text { Observed } \\
\text { category }\end{array}$ & $\begin{array}{l}\text { SMR } \\
(\mathrm{N})\end{array}$ & $95 \% \mathrm{Cl}$ \\
\hline \multicolumn{6}{|l|}{ Larynx (161) } \\
\hline Guberan et al, 1993 (20) & Switzerland & Self-employed butchers & 6 & 1.8 & $0.8-3.6$ \\
\hline Coggon \& Wield, 1995 (19) & UK & Butchers & 5 & 0.8 & $0.3-1.9$ \\
\hline Boffetta et al, 2000 (21) & Sweden & Butchers or meatpackers & 47 & 1.7 & $1.2-2.3$ \\
\hline \multicolumn{6}{|l|}{ Lung (162) } \\
\hline Doerken \& Rehpenning, 1982 (15) & Germany & & 36 & "2 fold" &.. \\
\hline Johnson et al, 1986 (12) & US & White males in union & 151 & 1.5 & $1.3-1.8$ \\
\hline Johnson et al, 1986 (13) & US & Women in union & 38 & 2.2 & $1.6-3.0$ \\
\hline Coggon et al, 1989 (18) & UK & Meat industry workers & 42 & 1.3 & $1.0-1.8$ \\
\hline Johnson, 1989 (14) & $\begin{array}{l}\text { US } \\
\text { US }\end{array}$ & $\begin{array}{l}\text { Nonwhite males in slaughterhouses } \\
\text { Nonwhite male meat packers }\end{array}$ & $\begin{array}{r}23 \\
9\end{array}$ & $\begin{array}{l}2.1 \\
1.0\end{array}$ & $\begin{array}{l}1.4-3.1 \\
0.5-1.9\end{array}$ \\
\hline Guberan et al, 1993 (20) & Switzerland & Self-employed butchers & 35 & 1.2 & $0.9-1.6$ \\
\hline Johnson, 1994 (16) & $\begin{array}{l}\text { US } \\
\text { US }\end{array}$ & $\begin{array}{l}\text { Women in supermarket } \\
\text { Men in supermarket }\end{array}$ & $\begin{array}{r}40 \\
102\end{array}$ & $\begin{array}{l}1.6 \\
1.1\end{array}$ & $\begin{array}{l}1.1-2.2 \\
0.9-1.3\end{array}$ \\
\hline Johnson et al, 1995 (17) & $\begin{array}{l}\text { US } \\
\text { US }\end{array}$ & $\begin{array}{l}\text { Abattoir workers } \\
\text { Meatpacking plant workers }\end{array}$ & $\begin{array}{l}167 \\
130\end{array}$ & $\begin{array}{l}1.4 \\
1.5\end{array}$ & $\begin{array}{l}1.2-1.6 \\
1.3-1.8\end{array}$ \\
\hline Coggon \& Wield, 1995 (19) & UK & Butchers & 294 & 1.0 & $0.9-1.1$ \\
\hline Boffetta et al, 2000 (21) & Sweden & Butchers or meatpackers & 314 & 1.3 & $1.2-1.5$ \\
\hline Fritschi et al, 2003 (22) & Australia & Male union members & 18 & 1.6 & $1.0-2.6$ \\
\hline McLean et al, 2004 (23) & New Zealand & Slaughterhouse workers & 23 & 1.8 & $1.1-2.7$ \\
\hline \multicolumn{6}{|c|}{ Lymphatic \& hematopoietic cancers (200-208) } \\
\hline Johnson et al, 1986 (12) & US & White males in union & 34 & 1.0 & $0.7-1.3$ \\
\hline Johnson et al, 1986 (13) & US & Women in union & 12 & 0.9 & $0.5-1.5$ \\
\hline Guberan et al, 1993 (20) & Switzerland & Self-employed butchers & 9 & 1.2 & $0.6-2.1$ \\
\hline Johnson, 1994 (16) & US & Women in supermarket & 17 & 1.4 & $0.8-2.2$ \\
\hline & US & Men in supermarket & 17 & 0.6 & $0.3-1.0$ \\
\hline Fritschi et al, 2003 (22) & Australia & Male union members & 20 & 1.0 & $0.6-1.6$ \\
\hline & Australia & Female union members & 4 & 0.9 & $0.2-2.3$ \\
\hline McLean et al, 2004 (23) & New Zealand & Slaughterhouse workers & 6 & 1.0 & $0.4-2.1$ \\
\hline \multicolumn{6}{|l|}{ Hodgkin's disease (201) } \\
\hline Johnson et al, 1986 (12) & US & White males in union & 9 & 1.5 & $0.7-2.7$ \\
\hline Coggon et al, 1989 (18) & UK & Meat industry & 2 & 2.4 & $0.3-8.7$ \\
\hline Guberan et al, 1993 (20) & Switzerland & Self-employed butchers & 2 & 2.5 & $0.4-7.9$ \\
\hline Coggon \& Wield, 1995 (19) & UK & Butchers & 2 & 0.8 & $0.1-2.9$ \\
\hline Boffetta et al, 2000 (21) & Sweden & Butchers or meatpackers & 11 & 0.8 & $0.4-1.4$ \\
\hline \multicolumn{6}{|l|}{ Non-Hodgkin's Iymphoma $(200,202)$} \\
\hline Johnson et al, 1986 (13) & US & Women in union & 5 & 0.8 & $0.3-1.8$ \\
\hline Johnson et al, 1986 (12) & US & White males in union & 16 & 1.1 & $0.6-1.7$ \\
\hline Guberan et al, 1993 (20) & Switzerland & Self-employed butchers & 2 & 1.3 & $0.2-3.9$ \\
\hline Coggon \& Wield, 1995 (19) & UK & Butchers & 7 & 0.7 & $0.3-1.4$ \\
\hline Boffetta et al, 2000 (21) & Sweden & Butchers or meatpackers & 66 & 1.0 & $0.8-1.2$ \\
\hline McLean et al, 2004 (23) & New Zealand & Slaughterhouse workers & 4 & 1.5 & $0.5-3.5$ \\
\hline \multicolumn{6}{|l|}{ Multiple myeloma (203) } \\
\hline Coggon et al, 1989 (18) & UK & Meat industry & 2 & 2.4 & $0.3-8.8$ \\
\hline Coggon \& Wield, 1995 (19) & UK & Butchers & 5 & 0.6 & $0.2-1.5$ \\
\hline Boffetta et al, 2000 (21) & Sweden & Butchers or meatpackers & 30 & 0.8 & $0.6-1.2$ \\
\hline \multicolumn{6}{|l|}{ Leukemia (204-208) } \\
\hline Johnson et al, 1986 (13) & US & Women in union & 5 & 1.0 & $0.4-2.1$ \\
\hline Johnson et al, 1986 (12) & US & White males in union & 8 & 0.6 & $0.3-1.1$ \\
\hline Coggon et al, 1989 (18) & UK & Meat industry & 3 & 1.4 & $0.3-4.2$ \\
\hline Guberan et al, 1993 (20) & Switzerland & Self-employed butchers & 5 & 1.7 & $0.7-3.5$ \\
\hline Johnson, 1994 (16) & US & Women in supermarket & 6 & 1.3 & $0.5-2.8$ \\
\hline & US & Men in supermarket & 6 & 0.5 & $0.2-1.2$ \\
\hline Coggon \& Wield, 1995 (19) & UK & Butchers & 8 & 0.5 & $0.2-1.1$ \\
\hline McLean et al, 2004 (23) & New Zealand & Slaughterhouse workers & 2 & 0.9 & $0.2-2.8$ \\
\hline
\end{tabular}

a Code of the ninth revision of the International Classification of Diseases in parentheses after the class of cancer. 
the group that had worked exclusively in nonmeat companies. The only hematologic cancers to show a (nonstatistically significant) excess risk were Hodgkin's disease and multiple myeloma (17).

A cohort of 1610 male slaughterhouse workers, employed for at least 6 months at one of three companies in the United Kingdom during the period 1946 to December 1971, was followed to the end of 1986 (18). Allcause mortality was lower than expected, as was mortality from respiratory disease, digestive disease, cerebrovascular disease, and ischemic heart disease. By contrast, an excess of mortality from all cancers was observed, due largely to excesses of cancers of the lung, stomach, and liver. A small excess of hematologic cancers was found, with eight deaths observed compared with 5.2 expected. When categorized by job title according to exposure to live animals, warm (freshly slaughtered) meat, chilled meat, and bacon process and products, the highest lung cancer risk (SMR 1.84, 95\% CI 1.15-2.79, 22 deaths) was observed for workers who had worked with warm meat. Another group of 4018 men whose occupation was listed as butcher in the 1961 census of England and Wales were followed to 1992 (19). Mortality from all cancers was close to expected, and no excess mortality from lung cancer was found. The authors noted several limitations of this study, however, including a high proportion of study subjects who could either not be traced or for whom only a probable match could be made and the lack of information on duration of employment of study subjects.

A small Swiss cohort of 552 butchers (cattle and sheep) and 310 pork butchers, working in Geneva during the period 1901 to 1969 and followed to 1990, experienced a significant increase in both all-cause and allcancer mortality (20). An elevated incidence of lung cancer was observed, as was an elevated incidence of colorectal, liver, and prostate cancer. Although no elevation was observed for hematologic cancers, an eightfold excess of leukemia cases ( 5 compared with 0.6 expected) was noted among butchers born before 1900a period in which all butchers slaughtered their own stock. In a Swedish record-linkage study, a cohort of 25049 men recorded as working as butchers or meatpackers, or as being employed in butcher shops, meat processing or packing, in either the 1960 or 1970 census was followed for cancer incidence and mortality for the period 1971 to 1989 (21). There was overlap in this cohort with the early report by Fox et al (5), although the follow-up period was considerably longer. A statistically significant increase in lung and laryngeal cancer was observed for those employed as butchers or meat workers in either census. An elevated risk of lung cancer was also observed for butchers working specifically in the meat industry [relative risk (RR) $1.40,95 \% \mathrm{CI}$ 1.10-2.00, 43 cases], using all other workers (excluding those employed in animal-related jobs) as a reference group. A nonsignificant increase in nonlymphocytic leukemia (SMR 1.30, 95\% CI 0.90-1.80) was also observed for those employed as butchers or meat workers at either census.

Two recent Australasian cohort studies have also found an excess risk of cancer, specifically lung cancer, for meat workers. Fritschi et al (22) studied a cohort of 19229 meat workers who were union members in Australia. The male workers had an increased risk of mortality from all causes and an increased incidence of lung cancer, but no significant associations with specific exposures were found. McLean et al (23) studied a cohort of 6647 meat workers in New Zealand, followed from 1988 to 2000. Mortality from all cancers was elevated, and there was a significant excess of lung cancer. Subgroup analyses showed statistically significant trends of increasing lung cancer risk with increasing duration of employment in jobs with the potential for exposure to biological material contained in animal blood and fecal matter. The risk was trebled for those with $>15$ years of employment in jobs with potential exposure to blood (SIR 3.07, 95\% CI 1.58-5.46, 10 cases) and fecal matter (SIR 2.97, 95\% CI 1.52-5.26, 10 cases). Despite the small numbers, there was some evidence of a dose-response relation between the incidence of hematologic cancers and an increasing duration of employment in jobs with potential exposure to animal fecal matter.

\section{Case-control studies}

The case-control studies conducted to investigate associations between cancer and work in the meat industry (24-26, 27-38) are reviewed below by disease category, with a summary of their findings presented in table 4. Within the limitations imposed by the type of exposure information available, which ranged from routine data sets to more-detailed information obtained from questionnaires or cohort records, these studies have provided additional insight into the exposures that may be responsible and in several cases have permitted adjustment for smoking.

Lung cancer. The first of the studies of lung cancer among butchers to control for smoking was a reanalysis of a previously collected case-control series of 1190 white male patients with lung cancer in Buffalo, New York, during the period 1957-1965 and 2124 controls selected from white male nonrespiratory, noninfectious and noncancer patients admitted during the same period (24). Twenty-one of the lung cancer cases, and 32 controls, had ever been employed in meat-cutting or packing-related industries, giving an odds ratio of 1.1 , which reduced to 1.0 when adjustment was made for smoking. 
Table 4. Case-control studies of cancer in meat workers. (RE = risk estimate, US = United States, $95 \% \mathrm{Cl}=95 \%$ confidence interval)

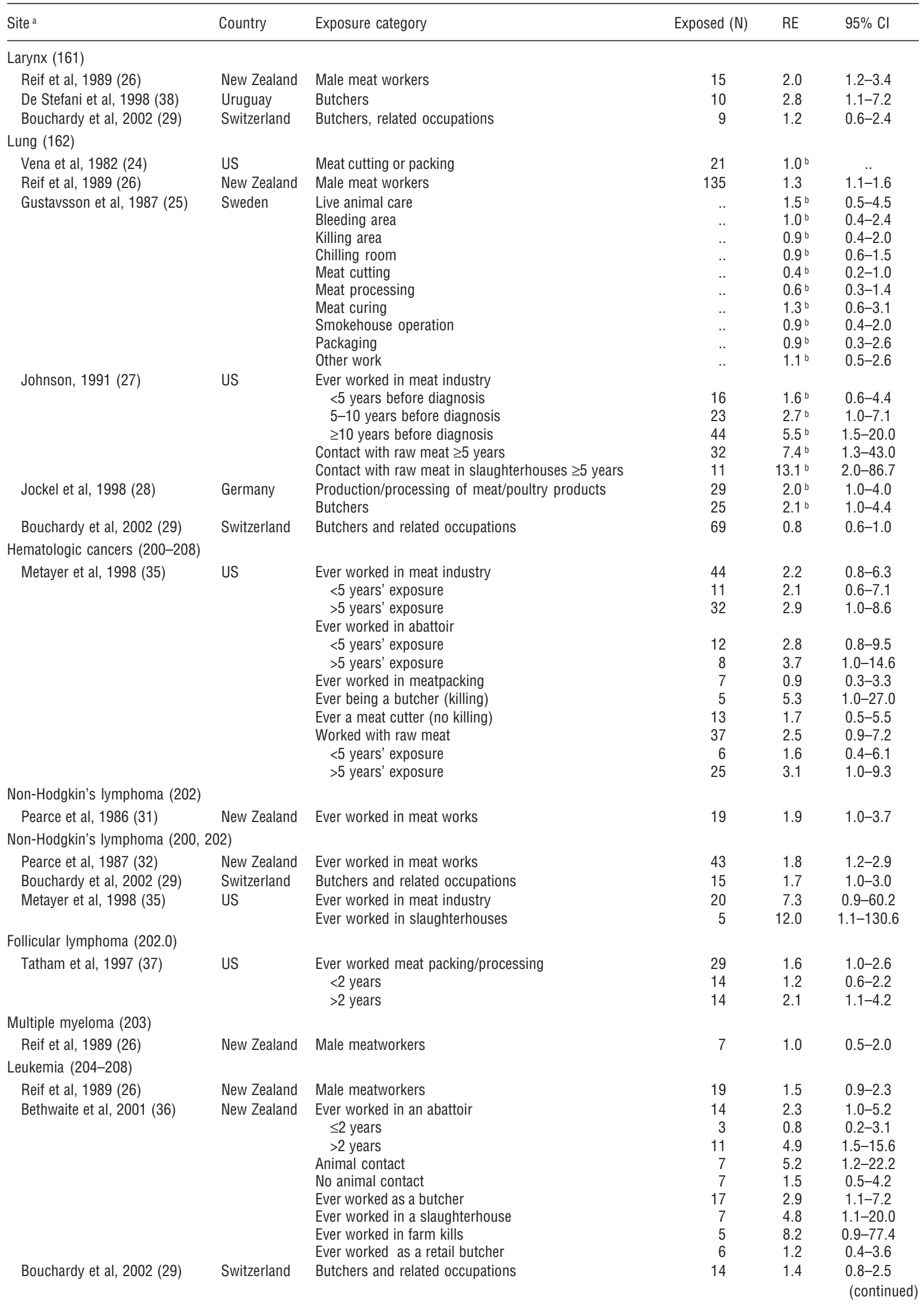


Table 4. Continued.

\begin{tabular}{|c|c|c|c|c|c|}
\hline Site $^{a}$ & Country & Exposure category & Exposed (N) & RE & $95 \% \mathrm{Cl}$ \\
\hline \multicolumn{6}{|c|}{ Acute myelogenous leukemia (205.0) } \\
\hline Reif et al, 1989 (26) & New Zealand & Male meatworkers & 9 & 2.1 & $1.1-4.1$ \\
\hline Pearce et al, 1986 (31) & New Zealand & Ever worked in meat works & 9 & 2.5 & $1.2-5.3$ \\
\hline \multicolumn{6}{|c|}{ Acute lymphoblastic leukemia (204.0) } \\
\hline Loomis \& Savitz, 1991 (34) & US & Routinely coded occupation & .. & 2.2 & $0.7-7.0$ \\
\hline \multicolumn{6}{|l|}{ Myeloid (205) } \\
\hline Bouchardy et al, 2002 (29) & Switzerland & Butchers and related occupations & 5 & 1.2 & $0.5-3.1$ \\
\hline \multicolumn{6}{|l|}{ Lymphoid (204) } \\
\hline Bouchardy et al, 2002 (29) & Switzerland & Butchers and related occupations & 9 & 2.4 & $1.2-5.0$ \\
\hline \multicolumn{6}{|l|}{ Chronic lymphatic } \\
\hline Bouchardy et al, 2002 (29) & Switzerland & Butchers and related occupations & 9 & 2.7 & $1.3-5.7$ \\
\hline
\end{tabular}

a Code of the ninth revision of the International Classification of Diseases in parentheses after the class of cancer.

${ }^{\mathrm{b}}$ Adjusted for race, gender, year of birth, and smoking.

Another study investigated lung cancer in butchers and slaughterhouse workers registered in the Swedish national census of 1960 (25). Men who had died of lung cancer between 1971 and 1982 were compared with two reference groups, namely, all men who had died of any type of cancer and a random sample of men who had died from any cause. Information on work history, occupational exposures, and smoking was obtained from next of kin, and the study participants were categorized according to exposure to work with live animals, in the bleeding area, on the killing floor, or with meat cutting, processing, curing, smoking, chilling, and packaging. No statistically significant increase in the rate of lung cancer was found to be associated with any of the occupational categories studied.

A New Zealand national cancer-register-based casecontrol study evaluated cancer risks for 19904 men recorded during 1980-1984, with registrants for all other sites as the reference group (26). Excess risks for lung and laryngeal cancer were observed for those whose occupation was recorded as "meat worker". Although there was no consistent elevation in risk for other smoking-related sites, the census data indicated that meat workers were more likely than the overall full-time male workforce to be current or ever smokers. Using the method of Axelson (39), the likely magnitude of the risk attributable to the higher smoking rates in this group was estimated to be 1.20 for lung cancer and 1.16 for laryngeal cancer; therefore it was concluded that at least a part of the increased risk observed was likely to be due to cigarette smoking.

Johnson (27) reported a case-control study of lung cancer nested within the Baltimore union cohort. Of the 289 cohort members who had died of lung cancer, 60 were selected at random for the case group, which was compared with a control group of 60 selected from among all other deceased members of the cohort who had not been diagnosed with lung cancer. Information on exposures and potential confounders for all the study subjects were obtained from next of kin by telephone interview. Although of limited statistical power, this study suggested an excess risk of lung cancer among those who had ever worked in the meat industry, with a suggestion of a latency-response based on the time between first exposure in the meat industry and diagnosis. It also found a strong association between contact with raw meat for $\geq 5$ years and contact with raw meat in a slaughterhouse for $\geq 5$ years, both of which supported Coggon's earlier findings of an increased risk in association with exposure to warm (freshly slaughtered) meat.

A recent West German case-control study of occupational risk factors for lung cancer found a twofold excess of lung cancer in association with the industry classification "production and processing of meat and poultry meat products", and also with the job title "butcher", in both instances after adjustment for smoking and asbestos exposure (28). By contrast, no elevation was found for cancer of the lung in the occupational category "butchers and related occupations" in a study of incidence data for all adult males from five of the eight Swiss cancer registers for 1980-1993 (29).

Hematologic cancers. The series of New Zealand registry-based case-control studies that examined hematologic cancer risks in association with agricultural occupations consistently found an elevated risk for meat workers, including excess acute myeloid leukemia (30), an elevated risk of leukemia that was most pronounced for acute myeloid leukemia (26), and elevated risk of non-Hodgkin's lymphoma (OR 1.8, 90\% CI 1.2-2.6, 43 exposed cases) $(31,32)$. Whittaker (33) published case notes from a planned case-control study of acute lymphoblastic leukemia in Wales. It showed that 5 of 33 cases gave an occupational history of working in a slaughterhouse or as a butcher (33). It was noted that 
none of the controls, who were selected from patients admitted to the same hospitals and were matched for age, gender, and area of residence, had worked with meat either as a butcher or slaughterhouse worker. In another study 5147 male leukemia deaths from 16 states in the United States were compared with 51470 men who died from other causes. According to the last known occupation listed on the death certificate, a nonstatistically significant increase in risk of acute lymphocytic leukemia for the occupational group "butchers and meat cutters" was found (34).

Another case-control study nested within the Baltimore union cohort investigated a range of risk factors for hematologic cancers within the meat-processing industry (35). All the deaths that had occurred from these cancers during the original study period of 1949 to 1980, plus an additional four subsequent deaths for which death certificates were available, formed the case group. The controls were selected at random from cohort members who had died of any other cause. As the response rate from the control group was low, an additional control group that had been used in the earlier nested casecontrol study of lung cancer was added to achieve 1:2 matching. Interviews were conducted with next of kin of both the cases and controls to obtain information on lifetime occupational exposures, with the information on employment history supplemented with information contained in the union records. For all hematologic cancer, an increase in risk was associated with ever having worked in the meat industry, and the association was stronger for those with $>5$ years of exposure. When the workers were categorized according to type of job, the strongest risk was observed for those who had ever worked in an slaughterhouse or in the meat department of a supermarket, but not in a meatpacking plant, the elevation in risk associated with work in a slaughterhouse being greater for those with $>5$ years of exposure. When categorized by type of exposure, a far higher elevation in risk was observed for those who had ever worked slaughtering animals than among those who worked as a meat cutter but did no slaughtering. The highest risk was observed for those with $>5$ years working with raw meat, confined to those who had worked with raw meat in an slaughterhouse or supermarket but not in a meat-packing plant.

Another New Zealand case-control study of acute leukemia, which compared 110 incident leukemia cases with 199 general population controls, showed an elevated risk for slaughterhouse workers and certain butchers (36). Occupational exposure histories were obtained by interview, and the departments and job tasks undertaken in a slaughterhouse were divided according to whether or not there was direct contact with live animals or animal tissues. Work in a slaughterhouse for a period exceeding 2 years was found to be associated with an increased risk of both acute nonlymphocytic and acute lymphoblastic leukemia, the increased acute nonlymphocytic leukemia risk being confined to those workers with contact with animals or animal products. Work as a butcher was also associated with an increased risk, but it was confined to butchers in slaughterhouses and those who butchered stock on a farm, no increased risk being found for work as a retail or wholesale butcher or meatpacker.

In a case-control study of occupational exposures and non-Hodgkin's lymphoma in the United States, cases of small-cell diffuse lymphomas $(\mathrm{N}=185)$, follicular lymphomas $(\mathrm{N}=268)$, and large-cell diffuse lymphomas $(\mathrm{N}=526)$ were selected from eight state populationbased cancer registers, and 1659 controls frequency matched for registry and date of birth in 5-year categories were selected at random from the general population (37). Telephone interviews were conducted with all the living cases and controls to obtain information on lifestyle, medical history, and a detailed work history. After control for several potential confounders, including smoking, a significant association was found between work in the meat packaging or processing industry and follicular lymphomas, although it was again confined to those with $>2$ years of exposure. The Swiss cancer-register-based study also found significantly elevated risks for non-Hodgkin's lymphyoma, lymphoid leukemia, and chronic lymphatic leukemia among those in the occupational category "butchers and related occupations" (29).

Other cancers. The only other cancer site for which a statistically significant increase among meat workers has been reported by more than one investigator in a casecontrol study is laryngeal cancer. A Uruguayan hospital-based case-control study reported increased risk in association with work as a butcher (OR 2.8, 95\% CI 1.17.2) after adjustment for potential confounders including smoking and alcohol consumption (38). This study thus supported the earlier finding of excess risk for laryngeal cancer (OR 2.0, 95\% CI 1.2-3.4, 15 exposed cases) among New Zealand meat workers (26), but not the finding from the Swiss cancer-register study (OR 1.2, 95\% CI 0.6-2.4, 9 cases) (29).

\section{Discussion}

In summary, although the available evidence is preliminary, reasonably consistent findings of excess cancers of the lung and of the lymphatic and hematopoietic system among meat industry workers in several studies suggest an increased risk within specific subgroups. 
In assessments of evidence for an association between work in the meat industry and increased cancer risks, it is necessary to evaluate the studies reviewed in this paper to determine whether the observed associations could be due to selection or information bias, to confounding, or to chance. Given the number of studies, the range of study types conducted, and the number of independent observations in different countries that have been made now over several decades, it is unlikely that any form of systematic error in either the selection or follow-up of the study subjects could explain these findings. Apart from the obvious limitations of reviews of routine data and proportionate mortality studies related to the comparability of numerator and denominator data, as in most epidemiologic studies, it is possible to identify the limitations of these investigations including issues related to study size and power particularly for the hematologic cancers, the reanalysis of existing datasets rather than the testing of hypotheses for which the studies were designed $(15,24)$, possible selection bias in the definition of the case group (35) or through loss to follow-up $(19,23)$, and possible information bias through obtaining exposure information from next of kin $(25,27)$, from union membership records $(11-14,16,17,22)$, census data at fixed points in time $(19,21)$, or from the last known occupation recorded on cancer registrations or death certificates (26, $34)$. There is, however, no obvious differential misclassification between exposed and unexposed groups that would introduce a bias in the same direction across all studies. Probably the most powerful form of selection bias that would apply in these studies is the healthy worker effect from comparing rates of disease in an initially healthy worker population with national rates, since the healthy worker effect typically results in lower relative mortality from all causes combined and to a less extent from all cancers (40). In this context it is interesting to note that, in all but one (22) of the meat workers' cohorts, cancer mortality rates in excess of national rates were observed.

The evidence for an increased risk of lung cancer among people occupationally exposed to meat and meat products is reasonably consistent, however, having been reported in several countries across different time periods and in a range of study types, including both cohort and case-control studies. In interpretations of these findings, it is also necessary to consider the possibility of uncontrolled confounding, and tobacco smoking is the strongest potential confounder in any study of the association between occupational exposures and the risk of lung cancer. While none of the cohort studies reviewed in this paper (12-23) had data on smoking, conclusions can still be drawn about the likely extent of the impact of differences in rates of smoking on the rates of lung cancer observed. Even where comparisons are made between rates of disease in an occupational cohort and in the general population, it has been shown that differences in smoking rates are unlikely to account for relative risks for lung cancer in excess of 1.5 (39), and, in the straight comparisons with national rates, the standardized mortality ratios observed for lung cancer among workers in the meat industry in these cohort studies ranged from 1.0 to 2.2. In addition, as differences in smoking rates between groups of manual workers are fairly small, confounding by smoking is likely to be minimal where internal comparisons are made (41), whereas internal comparisons have shown relative risks of up to three between unexposed and highly exposed workers $(18,23)$.

Indirect methods of adjustment for smoking, such as comparing rates of mortality from other smoking-related malignancies or from nonmalignant respiratory diseases, have also suggested that the observed excesses were not likely to be due to smoking $(18,23,26)$. In the case-control studies where smoking information was available, however, while two early studies found no elevation in risk after adjustment for smoking $(24,25)$, two more recent studies found that smoking did not explain the increased risks observed $(27,28)$.

Some chemical exposures in the meat-processing industry that were originally thought to be risk factors, such as those associated with the smoking and curing of meat, have been tested and excluded as possible causes (25). Additional potential chemical exposures in the meat industry include residues of hormone growth promoters and organochlorine pesticides. Residues of hormone growth promoters have been shown to be present in bovine urine in European slaughterhouses (42, 43), and workers on the slaughter floor are routinely exposed to animal urine, although these agents have seldom been used with sheep. Exposure to natural or synthetic hormones may disturb the endocrine system and increase the risk of hormone-dependent cancers such as breast or prostate cancer (44), and two of the hormone growth promoters, estradiol-17 beta and zeranol, have been shown to suppress the expression of a tumor suppression gene [protein tyrosine phosphatase gamma (PTP gamma)] in human breast tissue in vitro (45). Organochlorine pesticides, including DDT (dichloro-diphenyltrichloroethane) applied to pastures to control grass grub, lindane used as an insecticide for the control of lice among cattle, ectoparasites in sheep and grass grub in pasture, and aldrin and dieldrin in sheep sprays or dips to control ectoparasites, have been used widely in the past (46). The direct exposure of meat industry workers that would have occurred through the handling of treated stock would have ceased after the withdrawal of these products; however, routine residue monitoring in New Zealand indicates that the potential for exposure to DDT and its metabolites and to dieldrin remains through contact with meat products (47). 
The strongest associations found, however, were for workers involved directly with the slaughter of animals and with biological exposures. For the studies that were able to assess biological exposures, some $(23,27)$, but not all (22), found associations with lung cancer risk. In particular, McLean et al (23) found a significant association between lung cancer risk and years of employment in meat industry jobs involving exposure to biological material (blood and fecal matter). There is the potential in this industry for exposure to a range of biological agents: infectious agents including zoonotic diseases, noninfectious viable organisms, biogenic toxins produced by bacterial or fungal metabolism, and biogenic allergens such as proteins from animal skin, fecal matter or urine. The effects of exposure to biological agents are known to include contagious infectious diseases, acute toxic effects, allergies, and cancer (48). The physical nature of this work means that workers come into intimate contact with the blood and internal organs of animals, and with fecal matter or urine. Cuts and abrasions are frequent, and, as workers' hands are constantly wet, so also is dermatitis, all of which afford microbial agents access into the body through the skin. The process also results in the generation and transmission of bioaerosols, and airborne transmission is known to play a significant role in the spread of microbial contamination throughout the slaughterhouse environment (49). An early hypothesis for a biological cause was that there was an association with the virus responsible for the well-recognized high prevalence of warts among butchers (50), although in a subsequent investigation no DNA (deoxyribonucleic acid) from human papilloma virus (HPV) type 7 (or other HPV types associated with laryngeal and genital cancers) was found in histological material from the lung tumors of 40 butchers and 26 controls (51). There has also been considerable interest in retroviruses known to cause either malignant disease or immunosuppression in animals, in particular bovine leukemia virus (BLV) that infects both sheep and cattle and is closely associated with the development of leukemia and lymphoma in both species, although there are other oncogenic animal retroviruses such as sheep enzootic nasal tumor virus (ENTV), which causes tumors in the upper respiratory tract of sheep, and Jaagsiekte sheep retrovirus (JSRV), which causes ovine pulmonary adenomatosis (a transmissible lung cancer in infected sheep that resembles human bronchioalveolar carcinoma) (52). There is, however, little epidemiologic or experimental evidence of zoonotic viral causes of human malignancies. Moreover, in a recent study, cell samples taken from 44 patients with various malignant hematological diseases were tested for evidence of putative human oncoretroviruses using consensus polymerase chain reaction (PCR) primers developed from genome regions of known animal retroviruses. These PCR primers were capable of specifically amplifying type $\mathrm{C}$ and $\mathrm{D}$ exogenous animal retroviruses, without amplifying human endogenous retroviral elements, but no human homologues of nucleotide sequences of known animal oncoretroviruses (or related previously undetected human retroviruses) were found (53).

Overall these studies support the hypothesis that meat workers are at a significantly elevated risk of lung cancer, which is greater than that which could be attributed to smoking. It also appears that the risk is associated the most strongly with animal slaughtering and exposure to freshly slaughtered meat or to biological material contained in blood and animal fecal matter. This finding supports the hypothesis of an etiologic role for a biological exposure. The biological exposure(s) responsible are unknown, however, and further research is clearly required.

Elevated risks of hematologic cancers among meat industry workers have been observed in all the study types reviewed in this paper, although with these relatively rare cancers the numbers of cases were invariably small in cohort studies and the relative risks were generally lower than those observed in case-control studies. The risk factors that have been evaluated as potential causes of increased risk have generally been the same as those proposed for lung cancer (ie, chemical and biological exposures). The results of studies of hematologic cancers overall have been inconsistent, but they suggest an increased risk for those with either exposure to the slaughtering process or with a longer duration of exposure in the meat industry. The most consistent reports of increased risk for any of the subtypes of the hematologic cancers have been for leukemia, although this is not a single disease entity but rather a heterogeneous group of both myeloproliferative and lymphoproliferative disorders. The New Zealand case-control study of acute leukemia (36) provided strong support for the existence of an association between these cancers and work in the meat industry and, therefore, suggests that the risk is associated the most strongly with work as a butcher involved in slaughtering animals, rather than with work as a retail butcher, and with the duration of exposure. The evidence for any association between work in the meat industry and the lymphomas is much less consistent, and no elevation has been observed in any of the cohort studies conducted (table 3), although in all instances the numbers have been small. Thus the available evidence suggests a small excess in the risk of hematologic cancers in association with work in the meat industry, which is the most strongly associated with exposure to the slaughtering process and which is the most likely to be manifest as leukemia. However, these findings are most consistent in casecontrol studies, and there is less evidence of an increased risk in cohort studies. 


\section{Acknowledgments}

This work was funded by a project grant (HRC 00/281) from the Health Research Council of New Zealand. During the research, Dave McLean was supported by a Public Health Research Training Fellowship from the Health Research Council of New Zealand, and the Centre for Public Health Research is supported by a Programme Grant from the Health Research Council of New Zealand. Part of the work was completed during the tenure of a special training award at the International Agency for Research on Cancer.

\section{References}

1. Rothman KJ. Epidemiology: an introduction. New York (NY): Oxford University Press; 2002.

2. Cornfield J. A method of estimating comparative rates from clinical data: applications to cancer of the lung, breast and cervix. J Natl Cancer Inst 1951;11:1269-75.

3. Lynge, E. The Danish occupational cancer study. Geneva: International Labour Office; 1982. p 537-68. Occupational safety and health series 46 .

4. Lynge E, Andersen O, Kristensen TS. Lung cancer in Danish butchers. Lancet 1982;1(8323):527-8.

5. Fox AJ, Lynge E, Malker H. Lung cancer in butchers. Lancet 1982;1(8264):165-6.

6. Griffith GW. Lung cancer in butchers. Lancet 1982; 1(8268):399.

7. Kristensen TS, Lynge E. Lung cancer among butchers and slaughterhouse workers [review]. Scand J Work Environ Health 1993;19:137-47.

8. Lagorio S, Forastiere F, Rapiti E, Di Pietro A, Costa G. Attivita economiche e professioni ad elevato rischio di mortalita per tumore polomonare a Torino (1981-89) e in Italia (1981-82) [Economic activities and professions at high risk of mortality for lung cancer in Turin (1981-89) and in Italy (1981-82)]. Med Lav 1995;86:309-24.

9. Morton W, Marjanovich D. Leukemia incidence by occupation in the Portland-Vancouver metropolitan area. Am J Ind Med 1984;6:185-205.

10. Milham S. Lung cancer in butchers. Lancet 1982;1:690.

11. Johnson ES, Fischman HR. Cancer mortality among butchers and slaughterhouse workers. Lancet 1982;1(8277):913-4.

12. Johnson ES, Fischman HR, Matanoski GM, Diamond E. Cancer mortality among white males in the meat industry. J Occup Med 1986;28:23-32.

13. Johnson ES, Fischman HR, Matanoski GM, Diamond E. Occurrence of cancer in women in the meat industry. $\mathrm{Br} \mathrm{J}$ Ind Med 1986;43:597-604.

14. Johnson ES. Mortality among non-white men in the meat industry. J Occup Med 1989;31:270-2.

15. Doerken H, Rehpenning W. Lung cancer in butchers. Lancet 1982;1:561.

16. Johnson ES. Cancer mortality among workers in the meat department of supermarkets. Occup Environ Med 1994; 51:541-7.

17. Johnson ES, Dalmas D, Noss J, Matanoski GM. Cancer mortality among workers in abattoirs and meatpacking plants: an update. Am J Ind Med 1995;27:389-403.

18. Coggon D, Pannett B, Pippard EC, Winter PD. Lung cancer in the meat industry. Br J Ind Med 1989;46:188-91.

19. Coggon D, Wield G. Mortality of butchers and cooks identified from the 1961 census of England and Wales. Occup Environ Med 1995;52:157-9.

20. Guberan E, Usel M, Raymond L, Fioretta G. Mortality and incidence of cancer among a cohort of self employed butchers from Geneva and their wives. Br J Ind Med 1993;50:1008-16.

21. Boffetta P, Gridley G, Gustavsson P, Brennan P, Blair A, Ekström AM, et al. Employment as butcher and cancer risk in a record-linkage study from Sweden. Cancer Causes Control 2000;11:627-33.

22. Fritschi L, Fenwick S, Bulsara M. Mortality and cancer incidence in a cohort of meatworkers [electronic paper]. Occup Environ Medicine 2003;60:e4. [accessed: 2 November 2004; available from http://oem.bmjjournals.com/]

23. McLean D, Cheng S, 't Mannetje A, Woodward A, Pearce N. Mortality and cancer incidence in New Zealand meat workers. Occup Environ Med 2004;61:541-7.

24. Vena JE, Byers T, Swanson M, Cookfair D. Lung cancer in butchers. Lancet 1982;2:713.

25. Gustavsson P, Fellenius E, Hogstedt C. Possible causes of increased lung cancer incidence among butchers and slaughterhouse workers. Scand J Work Environ Health 1987;13:51823.

26. Reif JS, Pearce NE, Fraser J. Cancer risks among New Zealand meat workers. Scand J Work Environ Health 1989;15:249.

27. Johnson ES. Nested case-control study of lung cancer in the meat industry. J Natl Cancer Inst 1991;83:1337-9.

28. Jockel KH, Ahrens W, Jahn I, Pohlabeln H, Bolm-Audorff U. Occupational risk factors for lung cancer: a case-control study in West Germany. Int J Epidemiol 1998;27:549-60.

29. Bouchardy C, Schüler G, Minder C, Hotz P, Bousquet A, Levi $\mathrm{F}$, et al. Cancer risk by occupation and socioeconomic group among men - a study by The Association of Swiss Cancer Registries. Scand J Work Environ Health 2002;28 Suppl 1:188.

30. Pearce NE, Sheppard RA, Howard JK, Fraser J, Lilley BM. Leukemia among New Zealand agricultural workers, a cancer registry-based study. Am J Epidemiol 1986;124:402-9.

31. Pearce NE, Smith AH, Howard JK, Sheppard RA, Giles HJ, Teague CA. Non-Hodgkin's lymphoma and exposure to phenoxyherbicides, chlorophenols, fencing work, and meat works employment: a case-control study. Br J Ind Med 1986;43:7583.

32. Pearce NE, Sheppard RA, Smith AH, Teague CA. Non-Hodgkin's lymphoma and farming: an expanded case-control study. Int J Cancer 1987;39:155-61.

33. Whittaker JA. Acute lymphoblastic leukemia in butchers and abattoir workers. Br J Haematol 1991;79:649-51.

34. Loomis DP, Savitz DA. Occupation and leukemia mortality among men in 16 states: 1985-1987. Am J Ind Med 1991; 19:509-21.

35. Metayer C, Johnson ES, Rice JC. Nested case-control study of tumors of the hemopoietic and lymphatic systems among workers in the meat industry. Am J Epidemiol 1998;147:72738.

36. Bethwaite P, McLean D, Kennedy J, Pearce N. Adult-onset leukemia and employment in the meat industry: a New Zealand case-control study. Cancer Causes Control 2001;12:635643.

37. Tatham L, Tolbert P, Kjeldsberg C. Occupational risk factors 
for subgroups of non-Hodgkin's lymphoma. Epidemiology 1997;8:551-8.

38. De Stefani E, Boffetta P, Oreggia F, Ronco A, Kogevinas M, Mendilaharsu M. Occupation and the risk of laryngeal cancer in Uruguay. Am J Ind Med 1998;33:537-42.

39. Axelson O. Aspects on confounding in occupational health epidemiology [letter to the editor]. Scand J Work Environ Health 1978;4:98-102.

40. Checkoway H, Pearce N, Crawford-Brown DJ. Research methods in occupational epidemiology. New York (NY): Oxford University Press; 1989.

41. Siemiatycki J, Wacholder S, Dewar R, Wald L, Begin D, Richardson L. Smoking and degree of occupational exposure: are internal analyses in cohort studies likely to be confounded by smoking status? Am J Ind Med 1988;13:59-69.

42. Daeseleire EA, De Guesquiere A, Van Peteghem CH. Multiresidue analysis of anabolic agents in muscle tissues and urines of cattle by GC-MS. J Chromatogr Sci 1992;30:40914.

43. Haughey SA, Baxter GA, Elliot CT, Persson B, Jonson C, Burling P. Determination of clenbuterol residues in bovine urine by optical immunobiosensor assay. J AOAC Int 2001;84:1025-30.

44. Zacharewski T. Identification and assessment of endocrine disruptors: limitations of in vivo and in vitro assays. Environ Health Perspect 1998;106 Suppl: 577-82.

45. Liu S, Kulp SK, Sugimoto Y, Jiang J, Chang HL, Lin YC. Involvement of breast epithelial-stromal interactions in the regulation of protein tyrosine phosphatase-gamma (PTPgam- ma) mRNA expression by estrogenically active agents. Breast Cancer Res Treat 2002;71:21-35.

46. Buckland SJ, Bates MN, Garrett N, Ellis HK, van Maanen T. Concentrations of selected organochlorines in the serum of the non-occupationally exposed New Zealand population. Wellington (New Zealand): Ministry for the Environment; 2001.

47. Ministry of Agriculture and Forestry Biosecurity. Residue and species verification report-2000. Surveillance 2001;28:201.

48. Douwes J, Thorne PS, Pearce N, Heederik D. Biological agents - recognition. In: Perkins JL, editor. Modern industrial hygiene, vol 2: biological aspects. Cincinnati $(\mathrm{OH})$ : American Conference of Governmental Industrial Hygienists, Inc; 2003.

49. Rahkio TM, Korkeala HJ. Airborne bacteria and carcass contamination in slaughterhouses. J Food Prot 1997;60:38-42.

50. Pegum JS. Lung cancer in butchers. Lancet 1982;1:561.

51. Al-Ghamdi AA, Sanders CM, Keefe M, Coggon D, Maitland NJ. Human papilloma virus DNA and TP53 mutations in lung cancers from butchers. Br J Cancer 1995;72;293-7.

52. Burmeister T. Oncogenic retroviruses in animals and humans. Rev Med Virol 2001;11:369-80.

53. Burmeister T, Schwartz S, Thiel E. A PCR system for detecting oncoretroviruses based on conserved DNA sequence motifs of animal retroviruses and its application to human leukemias and lymphomas. J Gen Virol 82:2205-13.

Received for publication: 10 March 2004 